\title{
H2AC16 Gene
}

National Cancer Institute

\section{Source}

National Cancer Institute. H2AC16 Gene. NCI Thesaurus. Code C162904.

This gene is involved in histone-dependent nucleosome assembly. 